\title{
The Literature of Tiredness
}

\section{Kate McLoughlin}

\section{Introduction: Exhausted Literature}

The category of 'the literature of exhausted possibility' or, more succinctly, 'the literature of exhaustion' was famously posited by John Barth in 1967, writing, as he said later, as 'Mace and peppergas wafted through the academic groves'. ${ }^{1}$ By 'exhaustion', Barth clarified, he did not mean 'anything so tired' as 'the subject of physical, moral, or intellectual decadence', but only 'the used-upness of certain forms'. ${ }^{2}$ He gave by way of cultural example the Baroque, citing Jorge Luis Borges's definition: 'that style which deliberately exhausts (or tries to exhaust) its possibilities and borders upon its own caricature' ${ }^{3}$ Scrolls, crests, tendrils, trompes l'œil, valances, finials, scallops, baldachins, putti, curlicues: in this understanding, the whole riotous profusion is not so much a sign of luxurious abundance as the ironic visualization of the running out of ideas.

For Barth, the Borgesian image of exhaustion par excellence is the labyrinth: 'a place in which, ideally, all the possibilities of choice (of direction in this case) are embodied, and [...] must be exhausted' ${ }^{4}$ In the case of the three post-Second World War novels I propose to examine in this chapter-Elizabeth Taylor's A Wreath of Roses (1949), Angus Wilson's The Middle Age of Mrs Eliot (1958) and Iris Murdoch's An Unofficial Rose (1962) - the figure conveying artistic exhaustion is every bit as intricate as the labyrinth: the flower, most often the rose $\mathrm{e}^{5}$. After exploring this figure across the three texts, in the final section of the

\footnotetext{
${ }^{1}$ John Barth, 'The Literature of Exhaustion' [1967], The Friday Book: Essays and Other Non-Fiction (London: The Johns Hopkins University Press, 1984), 62-67: pp. 63, 64.

2 Ibid., p. 64.

${ }^{3}$ Quoted in ibid., p. 63; no reference for the Borges quotation is given.

${ }^{4}$ Ibid., p. 75.

${ }^{5}$ The three novels share more than a horticultural preoccupation. All of them feature at least one protagonist who is a war veteran: Richard Elton (who impersonates a veteran) and Morland Beddoes in A Wreath of Roses; Bill Eliot and David Parker (a Conscientious Objector who drove ambulances) in The Middle Age of Mrs Eliot; and Felix Meecham in An Unofficial Rose. The veteran functions as a figure for the spent or used-up. Two of
} 
chapter I address a more complex question: if these works depict artistic exhaustion, are they themselves also examples of exhausted literature? My response to that question involves adding nuance to Barth's definition with the help of Gilles Deleuze and a counter-illustration from Henry Green's 1946 novel Back, and positing a category of literary tiredness.

\section{Faded Garlands: Elizabeth Taylor's $A$ Wreath of Roses}

A Wreath of Roses takes as its epigraph a quotation from Virginia Woolf's The Waves (1931): 'I covered the whole street, Oxford Street, Piccadilly Circus, with the blaze and ripple of my mind, with vine leaves and rose leaves' (vi). ${ }^{7}$ Here, rose leaves are a means of distancing the self from the world: in the full original remark, Woolf's character, Rhoda, confesses immediately before the words quoted in the epigraph, 'So terrible was life that I held up shade after shade. Look at life through this, look at life through that; let there be rose leaves, let there be vine leaves.' 8 There is nothing Baroque about this proliferating foliage: the creative imagination has the energy to be fierily transformative. Taylor's novel portrays that imagination's limits. The character Richard Elton is characterized by the excessiveness of his tales. In their first extended encounter, he tells Camilla that he is says that he is going to Abingford to write a book:

'What kind of book?' she enquired.

'About the war.'

'Oh, I see.' ('The war and his experience in it,' she thought. 'Unreadable.') (5)

them-The Middle Age of Mrs Eliot is the exception-feature hair in the same way as roses, indeed, often entwining roses and hair. There is not space to develop the point here, but the whitening or thinning of hair seems to function as another barometer of cultural exhaustion.

${ }^{7}$ Elizabeth Taylor, A Wreath of Roses (London: Virago, 2011). Page numbers are given in the text.

${ }^{8}$ Virginia Woolf, The Waves (London: Grafton), p. 138. Notably, Woolf uses roses as a gauge of imaginationcritical imagination in this case - in her 1931 essay 'All About Books'. Acknowledging that '[n]o more respectable army has ever issued from the portals of the two great Universities', she questions the ability of the latest generation of critics to attend to 'the sound of the sea and the red of the rose' (Leonard Woolf, ed., Virginia Woolf: The Collected Essays (London: The Hogarth Press, 1966-67), vol. 2/4, pp. 266, 267). 
'Unreadable' suggests a literary production incapable of fulfilling its own raison d'être. This is confirmed when Camilla inquires further_-"What experiences did you have?" she felt obliged to ask. "What were you? What did you do?"' (6). Given that Elton has, in truth, had no combat experience, his answers are both insubstantial and extravagant: 'Dropped by moonlight half-way across France', 'Sat between Gestapo men in trains' (6). This time, the extravagance resembles Barth's and Borges's Baroque: it is the stuff of boys' adventure stories, of 'passwords, disguises, swallowing bits of paper, hiding others in currant buns' (6) - empty decoration rather than significant literary output. The conversation develops as follows:

'You must have great nerve,' she suggested, trying in this to find an excuse, a reason for the emptiness in his eyes.

'Not now,' he replied. 'The end of the war came at the right time for me. The last time I was briefed, a feeling of staleness came over me, a sort of tired horror . . '

'Tired horror!' she repeated, surprised. When he used those words, she could understand it all. (6)

This is a faux-exhaustion, expressed by a character who has not undergone what he claims to have drained him, but Elton's performance here is also a real literary exhaustion, a weary trotting out of clichéd forms. The same is true of the fantasies about his home and family that he spins to Frances later in the novel. His final story-about his strangulation of the girlhas energy for once: it is told succinctly, and with power. But now the exhaustion is transferred to his way of life, which comprises one hotel room after another as he remains on the run from the police. Camilla suddenly realizes that ' $[\mathrm{h}] \mathrm{e}$ is like this empty, cobwebbed house [...] Room after room of echoes, there's nothing there' (204). The image is of the labyrinth. His future consisting of only further circulation within the maze, Elton kills himself. That he is depicted doing so in exactly the same way as the suicide in the opening 
chapter means that his death, too, is merely repetitive. Elton is a Baroque figure or, in Taylor's preferred word, empty.

If Elton is a writer-manque (he has not started his book), the character Frances is a frustrated painter. In her youth, she was praised for her work but was herself dissatisfied with it until she 'willed herself into what she had painted' (92). Her teachers criticized her-'the apples, the dusters [...] seemed [...] not so much like apples and dusters as formerly'—but 'their verdict did not matter': '[t]he apple, the rose, were still the same, but violence swung about them' (92). This account suggests a vigorous beginning, full of possibility (here characterized as 'violence'). But, in later years, the energy dissipated, as Taylor reveals in an extended description of the now-elderly Frances's state of mind:

Frances awoke to her moss-roses. Each morning they annoyed her more, so endlessly repeated on a thick black trellis over the wall-paper, peeling away near the ceiling in places, leaving a powdery-looking but still flowered pattern exposed beneath. Violets, the one before last, Frances decided. Unless periwinkles. She thought about wall-papers, closing her eyes. She had painted many in her time, the great blown roses in the bedrooms of small French hotels: they had come into her pictures of littered chimney-pieces, rooms reflected in mirrors, the crumpled, tumbled beds, the naked girl holding her silk stocking to the light, her skin cream and apricot against the brilliant, the shocking crimsons, pinks, vermilions of the wall. [...] She closed her eyes and bunches of roses were printed for an instant startlingly white upon the darkness, then faded, as the darkness itself paled, the sun from the window coming brilliantly through her lids. (34)

Vigour has stagnated into repetition: roses - and they are the second-hand artificial roses of wall-paper, at that-have colonized and cluttered Frances's paintings. These ubiquitous roses are 'great blown roses', roses past their prime, both huge (excessive) and beginning to 
decay. They are repeated not only in the paintings but now, 'endlessly', on Frances's own bedroom wall-paper, annoying her and revealing the ghosts of other layers of flowers beneath them. Now, when Frances closes her eyes, she sees the after-images of roses-roses blanched of colour-spectral roses that lack even the substantiality of long-covered-over wall-paper roses. For a moment, there are roses on roses on roses, calling to mind Gertrude Stein's line 'Rose is a rose is a rose is a rose'. ${ }^{9}$ In Stein's phrase, signification becomes circular (like the labyrinth) and therefore empty: a rose can give no more information than that it is a rose. The palimpsestic wall-paper roses in Frances's bedroom make the same point in stratified form; then, insubstantial, they disappear, annihilated by nothing more than the sunlight. In the terms of this chapter, these roses are exhausted: literally over-loaded (pasted on top of each other), they have lost their signifying effectiveness and become mere irritants.

And to Frances's mind comes the thought that her work has been only 'sentimentality' (34) - a condition in which feeling exceeds substance. 'For was I not guilty of making ugliness charming?' she asks herself (34). Aiming at 'tenderness and intimacy', she has instead laid an 'English sadness like a veil over all [she] painted' until it became 'ladylike and nostalgic' (34). This muted description is another account of exhausted art, an art that has been unable to substantiate the 'violence, with flames wheeling, turmoil, pain, chaos' that lies at the heart of things (34). Of late, Frances has tried to produce a different kind of painting, to work 'from an inner darkness, groping and undisciplined' (92) but her most recent canvases are 'four utter failures to express her new feelings, her rejection of prettiness, her tearing-down of the veils of sadness, of charm' (35). ${ }^{10}$ Towards the end of the novel, Frances contemplates her final work, a 'creamy-pink and yellow picture, half a mirror

\footnotetext{
${ }^{9}$ The line, which Stein modified through a number of works, appeared originally in the 1913 poem 'Sacred Emily' (Gertrude Stein, Geography and Plays (Madison: University of Wisconsin Press, 1993), 178-88: p. 187). ${ }^{10} \mathrm{Cf}$. Anthony Blanche warning Charles Ryder in Brideshead Revisited (1945) that 'charm' - 'the great English blight'-'spots and kills anything it touches [...] kills love [...] kills art' (Evelyn Waugh, Brideshead Revisited (Harmondsworth: Penguin, 1982), pp. 311-12).
} 
with reflected hands lifting a wreath of roses, a flash of golden hair' (194). The palette is anodyne, the 'wreath' has funereal overtones, the mirror (long a figure of representative art) is fractured, the reflections suggest Baroque infinite repetition. Viewing it, Frances feels 'a great weariness' (193). She has 'no way to turn' (193):

There is no past for an artist. What is done is cast away, good only for the time of its creation. Work is the present and the immediate future; but her immediate future was a blank. (193)

The lack of a future vision marks the atrophying of possibilities. The next moment, Frances picks up the 'wreath of roses' lying on the work-bench and fingers the petals, 'soft and dead', that now comprise a 'faded garland' (194). The roses are serviceable now neither as floral crown nor as funeral wreath. Frances makes a final statement of artistic exhaustion: 'I shan't paint again' (194).

\section{'Vegetable Ease': Angus Wilson's The Middle Age of Mrs Eliot}

Horticulture was foundational to Angus Wilson's creative imagination, as he describes in detail in his memoir, The Wild Garden, or, Speaking of Writing (1963). At the 'very root' of his 'symbolic view of life' was the 'wild garden' and 'the clearing (or garden) in the wild', ${ }^{11}$ the former deriving from his father's childhood garden in Scotland, the latter from his mother's in South Africa, the one apparently rejecting progress (in the form of cultivation), the other apparently welcoming it. Gardening informs Wilson's entire fictional oeuvre, but changes over time. In The Middle Age of Mrs Eliot, it is used to demonstrate what Wilson calls 'a final abnegation of life'. ${ }^{12}$ Exhaustion is evident from the novel's start. In an early passage, Meg Eliot reflects upon the 'odious obverses' that occur throughout attempts to

\footnotetext{
${ }^{11}$ Angus Wilson, The Wild Garden, or, Speaking of Writing (Berkeley: University of California Press, 1963), p. 61.

${ }^{12}$ Ibid., p. 58.
} 
make 'some account of life' (32). ${ }^{13}$ In her husband, Bill, the 'offhand, easy indolence' with which he has 'smoothed out the tearing, breaking grind of the hard work that had given him his success' shows at such times as 'a drink-flushed, petulant, sensual coarseness, signalling red for thrombosis' (32). In Meg herself, a 'constant, hard-working eagerness to fill life with use and pleasure, to banish the spectre of her sex, class, and age' reveals an underside of 'hungry, lean exhaustion', signalling 'red for nervous headaches, breakdown —all the boring paraphernalia of the sort of unfilled life she had so successfully avoided' (32). In Barth's terms, the Eliots are exhausted, their time filled with Baroque activities that are simply performed for their own sake. Bill's secret gambling exhausts their money supply for no return and Meg's purchasing of antique ceramics merely circulates existing pieces. Their childlessness - and this is a theme that also appears in the other novels - completes a picture of non-productivity. ${ }^{14}$

In her recuperative stay at her brother, David's, nursery garden, Andredaswood, Meg encounters further cultural exhaustion. Quietist David, a Conscientious Objector who drove for the Friends' Ambulance Unit in Libya during the war, had previously been elected to an Oxford fellowship. ${ }^{15}$ But on his return from the war, he 'gave it all up' for the nursery in Sussex (53). To herself, Meg frames David's choice as one of 'isolation and hard manual work' (54), a way of life that might seem physically tiring, if mentally reinvigorating. A customer of the nursery comments in similar vein:

'I suppose the fascination of gardening lies a lot in the way one can plan for the future. Especially in such an insecure world. I open my morning paper and read of some fresh new horror the scientists have devised and then I plan some change in the

\footnotetext{
${ }^{13}$ Angus Wilson, The Middle Age of Mrs Eliot (Harmondsworth: Penguin, 1969). Page numbers are given in the text.

${ }^{14}$ In A Wreath of Roses, Liz's son Harry makes apparent Camilla's and Frances's childlessness; in An Unofficial Rose, Steve, the son of Randall and Ann Peronett, is dead.

${ }^{15}$ David is described as espousing 'quietism' by Wilson (The Wild Garden, p. 58). Margaret Drabble (Angus Wilson: A Biography (London: Secker \& Warburg, 1995), p. 248) and Marina Mackay ('Mr. Wilson and Mrs. Woolf', Journal of Modern Literature 23.1 (1999), 95-109: p. 98) pick up the word.
} 
garden that won't be fully realized for at least five or six years. It's illogical, of course, but it's some comfort.' (164)

In these remarks, gardening is the opposite of exhaustion: possibilities are planned for and enjoyed in their (literal) flowering. But David's internal reaction to the customer's comments realigns them:

[T] he idiotic sentimentality about 'gardening and the future' was right in its general line. Over the years he had built up a life encompassed by simple immediate duties and recreations - an ordered present; but an ordered present demanded at least the fiction of an immediate future with simple duties and recreations to be planned. Only such a life, he had come to believe, could allow one to cross the shapeless tract of human existence with grace and with gentleness; if the path was a meaningless progress to the grave, then the more necessary to take each step as a deliberate progress to the next; he could see no other way of preserving the fiction of civilization, and nothing to recommend the indulgence of exposing it. (165)

Gardening as a statement of future possibility is a 'sentimentality' (the same word used by Taylor of Frances's exhausted paintings), a 'fiction'. Though the nursery has obliged him to go through the motions of planning, it has nevertheless been at base a 'meaningless progress'. In this view, gardening is Baroque, a form which has no significance beyond itself. 'The nursery is exactly what it is,' thinks David, 'a well run commercial garden, supplying its customers with value for their money, paying its workers good wages' (119). In this last description, the nursery is not particularly profitable - it does not create anything, that isand it also fails to discharge any signifying duty: a nursery garden is a nursery garden is a nursery garden. 
Though Meg has come to the nursery to be restored (and this is not the place to deal with the psychoanalytical implications of this figurative regression to childhood), ${ }^{16}$ Andredaswood is itself exhausted. So, too, is David. His partner, Gordon, is dying in the house. In October, the nursery is full of dahlias and Michaelmas daisies, 'gaily garish with that commercial colourfulness', 'hardly beautiful', an 'obvious show' (317)—Baroque flowers, in other words. Tim Rattray decides upon 'a complete reorganization of the rose culture' (340): a redistribution of the status quo, that is, rather than a new venture. David, 'anxious to produce nothing that could add to all the personal voices that were leading mankind to boiling point', ${ }^{17}$ feels the book series that he and Gordon have been working on, Garden Flowers in their Homes, has the merit of 'insipidity' since it pretends 'to nothing' (331): this is repetitive, second-hand, exhausted work. In similar vein, Frederica GrantPritchard's 'sentimentalism' (the word, with all its significance, appears again) appeals to him, and he likes her plan for a 'complete restoration of the garden of 1905 with no “improvements", no later species or varieties, only renewal' (334): an example of artistic endeavour that has run out of ideas. He takes up Meg's suggestion of revising his thesis, and the two of them start to read eighteenth- and nineteenth-century novels together, with Meg preparing 'an ever-extending bibliography' (340). The activity is repetitious, taking them both back to the past and to past forms; the bibliography, like the garden reconstruction and the coffee-table books, exemplifies what Gilles Deleuze calls the 'combinatorial', the principle of 'combin[ing] the set of variables of a situation' until all possibilities have been exhausted. ${ }^{18}$ In a remark on Hardy, David reveals that he recognizes the phenomenon. 'Hardy could only fall back on melodrama when his immediate vision failed him,' he tells

\footnotetext{
${ }^{16}$ Wilson acknowledges the 'pun' in The Wild Garden, p. 58.

${ }^{17}$ It is notable that, at the time he was writing The Middle Age of Mrs Eliot, Wilson himself felt paralyzed by the weight of literary expectation: 'that so much is expected of one all the time makes me utterly miserable', he wrote to Richard Wollheim (quoted in Drabble, Angus Wilson, p. 240).

${ }^{18}$ Gilles Deleuze, 'The Exhausted' ['L'Épuisé' (1992)], trans. Anthony Uhlmann, SubStance 24.3 (1995), 3-28: p. 3 .
} 
Meg (280). Melodrama, like sentimentality, like the Baroque, is a mode of excess, 'hyperbolic' in its gestures, repetitive in its ideas, bordering on exhaustion - it is deployed in the absence of fresh inspiration. ${ }^{19}$ Though melodrama and quietism are ostensible opposites, what they have in common is an inability to add anything to the world. This trait—or lack of trait—is described by Wilson in The Wild Garden, in an extended account of how he intended the character of David to function:

David's involvement with gardening on a commercial basis is chosen by him very deliberately as a practical background to a contemplative quietist life; the botanical books that he and Gordon write are again deliberately a commercial venture. After the death of Gordon, who for all his faults of egotism and dominance, is committed to living, David's commercially chosen pursuit assumes a more and more routine dead form. If David, as I intended, stands for surrender to sloth, despair of humanity, deliberate destruction of the human will, all under a high-minded self-deception, then his perfunctory use of gardening becomes a characteristic abuse. ${ }^{20}$

'Surrender to sloth, despair of humanity, deliberate destruction of the human will': these comprise what I have been characterizing as exhaustion. Here it is inflected as a kind of lack of artistic integrity, a commercialization that produces only 'dead form'. David, who has succumbed to 'vegetable ease' (345) is 'utterly exhausted' (341).

\section{Complex Roses: Iris Murdoch's An Unofficial Rose}

A nursery garden is also the main setting in Iris Murdoch's An Unofficial Rose. Grayhallock rose nursery is Randall Peronett's 'creation' (11), ${ }^{21}$ and his rose cultivars are, it is underlined

\footnotetext{
19 Peter Brooks, The Melodramatic Imagination: Balzac, Henry James, Melodrama and the Mode of Excess New York: Columbia University Press, 1985), p. 3. Brooks's remark that melodrama represents 'the impossibility of conceiving sacralisation other than in personal terms' (p. 16) reinforces the idea that melodrama is exhausted tragedy: tragedy that has become merely personal, that is.

${ }^{20}$ Wilson, The Wild Garden, p. 59.

${ }^{21}$ Iris Murdoch, An Unofficial Rose (Harmondsworth: Penguin, 1964). Page numbers are given in the text.
} 
$(20,24)$, the means by which his name will be perpetuated. But Randall-mercurial, egotistical, unfaithful — who has been in his youth a 'remarkable horticulturalist' (24), is growing exhausted. In an early scene, having secluded himself from his family in his room, he is visited by his father, Hugh. There are 'three bowls of roses' on the table and the room smells of 'alcohol and roses' (28): roses here are part of a larger evocation of decay, a sense that 'the great days of the nursery were over' (24). Murdoch writes:

Hugh absently picked one of the roses out of the nearest bowl. Randall preferred the Moss roses and the old roses of Provence to the metallic pink of his own creations. Hugh looked at the rose. The petals, fading through shades of soft lilac, and bending back at the edges so that the rose was almost spherical, were closely packed in a series of spirals about a central green eye. (31)

It is noteworthy that Randall prefers the older roses to his own, more lurid creations: the suggestion is that the art of breeding roses is becoming exhausted in parallel with the breeder - in the absence of robust new varieties, there is nowhere to turn but to the past. Hugh, uniquely among the characters in the three novels under discussion, actually stops to look at a single rose. It is an old rose, complex, a structure of intricate spirals and variegated colours, and it anticipates the moment when Lindsay Rimmer, Randall's mistress, is described as 'a complex rose' (63). Randall's wife, Ann, by contrast, is, in Randall's view, 'as messy and flabby and open as a bloody dogrose' (32), 'deadeningly structureless' (64), and so 'destroys all [his] imagination' (32). While Hugh 'twirl[s]' the rose he has picked from the bowl (31) - an absent-minded gesture, but one that would reveal the flower's full splendour-Randall takes it from his father's hand and sinks back into his chair 'looking blank and limp, the rose pendant from one hand' (32). 'Christ, how I fade!' he exclaims (32). The rose marks both Hugh's current driftlessness and Randall's waning creative vigour. 
In a later scene, Randall, who is agonizing about leaving Grayhallock, goes to 'take a last look at the roses':

He felt like a sorcerer who has created a vast palace and adorned it with gold and peopled it with negroes and dwarfs and dancing girls and peacocks and marmosets, and then with a snap of his fingers makes it all vanish into nothing. [...] Here was the slope where he had first planted his roses [...] Here he had created Randall Peronett and Ann Peronett, names to keep company with Ena Harkness and Sam McGredy, and also his darling the white rose Miranda. They would live on, these purer distillations of his being, when their namesakes were only so much manure. He wondered, will I ever do all this, somewhere else, again, making roses with different names? Will I live through this whole cycle of creation again? And as some ambiguous voice in his heart answered no, and that he would now never breed a blue rose, or win the Gold Medal at the Paris Concours, or send Lindsay's name round the world in a catalogue, he told himself that he was tired of it all anyway: tired of the endless feverish race to market new floribundas and new hybrid teas, the endless tormenting of nature to produce new forms and colours far inferior to the old and having to recommend them only the brief charm of novelty. What was it all for, the expulsion of the red, the expulsion of the blue, the pursuit of the lurid, the metallic, the startling and the new? It was after all a vulgar pursuit. The true rose, the miracle of nature, owed nothing to the hand of man. (182-3)

Imagine that this internal monologue is about writing novels rather than breeding roses. It is a classic account of creative exhaustion (and it is an important point that Randall is also an unsuccessful playwright). The palace adorned with gold and peopled with negroes, dwarfs, dancing girls, peacocks and marmosets is pure Baroque: ornamentation for its own sake that simply repeats and increases what is already there. The latter part of the description rehearses 
Deleuze's combinatorial principle, the using-up of possibilities which leads to ever more fantastic art (the blue rose). The monologue resonates with the novel's epigraph, lines from Rupert Brooke's poem 'The Old Vicarage: Grantchester' (1912): 'Unkempt about those hedges blows / An English unofficial rose' (preliminary pages). As Peter Conradi notes, Brooke, writing in Berlin, was drawing a distinction between the 'orderly flowers' of Germany and the 'sweetly undisciplined' flowers of England. ${ }^{22}$ The distinction roughly parallels Wilson's 'garden in the wild' and 'wild garden'. There is something contrived, artificial about the orderly flowers, just as there is about the 'lurid', 'metallic' and 'startling' cultivars. (Wilson, who criticized An Unofficial Rose for its snobbery about 'old roses', ${ }^{23}$ confessed elsewhere to a 'horror' of such 'deliberate and perverse exploitation of nature'. $)^{24}$ In their different ways, both Brooke's neat Teutonic flower-beds and Randall's exotic varieties are instances of artistic impoverishment: the former because they indicate imaginative limitations, the latter because they are showy only. ${ }^{25}$ Overall, the monologue explains Randall's sense of feeling 'weary of Ann, weary of himself, and yet not able to conceive of any other life' (60), his inability to 'see himself starting again to build up, somewhere else in England, another rose nursery' (63). Though he does leave with Lindsay, financed by the sale of his father's Tintoretto (a work of art which, contrasting with the gaudy roses, glows with energy throughout the novel), Randall does not find new creative possibilities but a life of indulgence-exhaustion - in Italy, the land of ruins and Old Masters.

\footnotetext{
${ }^{22}$ Peter J. Conradi, The Saint and the Artist: A Study of the Fiction of Iris Murdoch [1986] (London: HarperCollins, 2001), p. 74.

${ }^{23}$ Angus Wilson, 'Who Cares', The Guardian (8 June 1962), p. 6.

${ }^{24}$ Wilson, The Wild Garden, p. 59.

${ }^{25}$ Cf. the Kroesigs' garden in Nancy Mitford's The Pursuit of Love (1945), which, despite the profusion of 'huge and hideous flowers, each individual bloom appearing twice as large, three times as brilliant as it ought to have been', is described as 'a riot of sterility' (Nancy Mitford, Love in a Cold Climate and Other Novels (London: Penguin, 2000), p. 74).
} 


\section{Not Exhausted, Only Tired}

The three novels under discussion, then, each depict instances of the exhaustion of the artistic imagination, whether this is literary, painterly or horticultural. These depictions are expressions of cultural anxiety: an artefact that portrays the exhaustion of art is inherently self-doubting. But to what extent are A Wreath of Roses, The Middle Age of Mrs Eliot and An Unofficial Rose themselves instances of exhausted literature? To answer this question requires returning to Barth's remarks on the subject, and adding to them observations made by Gilles Deleuze. In an essay written twelve years after 'The Literature of Exhaustion', Barth emphasized that his diagnosis had not meant that literature was 'kaput'. ${ }^{26}$ Rather, he argued in 'The Literature of Replenishment' (1980), used-up artistic conventions could be 'subverted, transcended, or even deployed against themselves' to generate 'new and lively work' ${ }^{27}$ A re-invigorated literature, that is - and what Barth had in mind was postmodern fiction - would take these exhausted possibilities, and exhaustion itself, as theme and form. ${ }^{28}$ It would, in other words, not simply re-use old plots, themes, imagery and devices in traditional manner but re-deploy them self-reflexively, ironically and playfully-and make the re-deployment itself its subject. A further twelve years after this, Deleuze, in an essay on Beckett, suggested a distinction between exhaustion and tiredness:

The tired no longer prepares for any possibility (subjective): he therefore cannot realize the smallest possibility (objective). But possibility remains, because you never realize all of the possible, you even bring it into being as you realize some of it. The

\footnotetext{
${ }^{26}$ John Barth, 'The Literature of Replenishment' [1980], The Friday Book: Essays and Other Non-Fiction (London: The Johns Hopkins University Press, 1984), 193-206: p. 205.

${ }^{27}$ Ibid., p. 205.

${ }^{28}$ This view of postmodernism has been challenged. Stephen Connor, for example, casts repetition (exhaustion) in a more positive light, arguing that postwar fiction 'established an important link between history and novelistic narrative [by] the practice of rewriting earlier works of fiction' (The English Novel in History: 1950 to the Present (London: Routledge, 1996), p. 166), while Mark Currie doubts Barth's very premise: 'It was always one of the least credible tenets of postmodern literary and cultural theory that we should think about the contemporary as a condition of blocked futurity, in which novelty is reduced to the simulation, repetition and recycling of past forms' (The Unexpected: Narrative Temporality and the Philosophy of Surprise (Edinburgh: Edinburgh University Press, 2013), p. 6).
} 
tired has only exhausted realization, while the exhausted exhausts all of the possible.

The tired can no longer realize, but the exhausted can no longer possibilitate. ${ }^{29}$

Deleuze adds eschatological overtones to Barth's definition: exhaustion is a state not only in which all possibilities have been used up but also in which no further or future possibilities can be imagined. Drawing on Barth and Deleuze, I would posit, not a literature of exhaustion, nor yet a literature of replenishment, but a literature of tiredness, or, less grandiosely, a literary tiredness. This is a tiredness that can envisage or hypothesize possibilities (which is what I think Deleuze meant by 'possibilitate') ${ }^{30}$ but is not able or inclined to realize them. I suggest that A Wreath of Roses, The Middle Age of Mrs Eliot and An Unofficial Rose all display this condition.

The possibility which the three novels can see, but not realize, is what Barth characterizes as replenishment: the rending of artistic exhaustion into form, as well as theme. But there does exist a novel in which such rendering occurs, using the figure of the rose, and that novel is Henry Green's Back (1946). Back features a veteran and former prisoner-ofwar, Charley Summers, who has returned, postwar, to his native village. Like many veterans, Charley is hard-pressed to make sense of the civilian world he has come back to. Green concentrates this sense of disconnect in Charley's refusal to believe that his former lover, Rose, has died while he has been away, and in his belief that another woman, Nancy (actually Rose's half-sister) is in fact Rose. Miscommunications and misunderstandings aboundbetween Charley and Nancy, between Charley and Rose's parents, between Charley and his new secretary Dot Miller. But Green does more than describe and dramatize the failure of signification: he realizes it. He does this by repeating the word 'rose' literally hundreds of

\footnotetext{
${ }^{29}$ Gilles Deleuze, 'The Exhausted', p. 3.

${ }^{30}$ The original line is 'Le fatigué ne peut plus réaliser, mais l'épuisé ne peut plus possibiliser' (Gilles Deleuze, 'L'Épuisé', Quad et Trio du Fantôme, ... que nuages..., Nacht und Träume by Samuel Beckett (Paris: Éditions de Minuit, 1992), 57-106: p. 57). My understanding of this is that the tired can no longer realize possibilities, though it can see them, while the exhausted is beyond the point of being able to see possibilities, let alone realize them. The French possibiliser and the English possibilitate both mean 'to render possible', which seems confusingly synonymous with 'realize', posited by Deleuze as their antonym.
} 
times. It occurs as the name of the flower, as the female name 'Rose', as the past tense of 'to rise'. When flowers are denoted, they are never differentiated by variety and, overwhelmingly, their colour is red. These myriad roses blur into one another, that is to say. An idea of the effect is gained from the following description of a rose garden (itself a literary topos of long standing $)^{31}$ which has been blasted by a bomb:

[T]hen they had before them, the outlines edged in red, stunted, seemingly withered, rose trees which had survived the blast as though it had never happened, and, for a screen at the back, a single line of dwarf cypresses, five feet high with brown trailing leafless briars looped from one to the other, from one black green foliage to its twin as green and black, briars that had borne gay rose, after rose, after wild rose. ${ }^{32}$

There are a number of repetitions in this passage, but the most notable — and it is typical of Green's prose throughout the novel — is 'gay rose, after rose, after wild rose', a particularly concentrated reiteration. Not for the first time in the work, Green calls to mind Gertrude Stein's phrase already mentioned above: 'Rose is a rose is a rose is a rose'. As noted earlier, in Stein's line, signification becomes circular. In Green's novel, the effect becomes what Rod Mengham describes as 'a form of surplusage'. ${ }^{33}$ Used to excess, that is, the rose is evacuated of meaning. Individually or en masse, Green's roses buckle under a weight of expectation, simply unable to discharge the signifying function that such reiteration and variation would seem to require. But the important point is that this emptiness of signification becomes the reader's experience - a personally lived and felt experience, rather than a subject to read about.

\footnotetext{
${ }^{31}$ Ten years before the publication of Back, in Eliot's 'Burnt Norton' (1936), the rose garden was at the height of its signifying potential, a topos in which, through the catalysing work of poetry, mutual exclusives (past, present and future; what might have been and what has been; dryness and water) could all be at once fully available. Far from exhausted, Eliot's rose garden brims with possibility to the point of saturation: 'human kind / Cannot bear very much reality' (T. S. Eliot, The Complete Poems and Plays (London: Faber and Faber, 1969), p. 172).

${ }^{32}$ Henry Green, Back (London: The Harvill Press, 1998), p. 174.

${ }^{33}$ Rod Mengham, The Idiom of the Time: The Writings of Henry Green (Cambridge: Cambridge University Press, 1982), p. 172.
} 
Back is an instance of the literature of replenishment. But the three novels I have been concentrating on, while they perceive and depict the phenomenon of artistic exhaustion, do not realize it. In this sense, they fit Deleuze's definition of tiredness: the ability to perceive, but not realize possibilities (exhaustion, it will be remembered, neither perceives nor realizes). Something of this tiredness seems to have conveyed itself to critics. A reviewer in The Times thought the characters in A Wreath of Roses 'strangely dimmed'. ${ }^{34}$ Rubin Rabinovitz considered The Middle Age of Mrs Eliot 'boring'. ${ }^{35}$ A. S. Byatt found 'something perfunctory, something lifeless' about An Unofficial Rose, sensing that Murdoch was 'wearily covering old ground, not living anything new'. ${ }^{36}$ These critical reactions make a further point: as yawning is contagious, so the literature of tiredness tires the reader, whose experience becomes that of witnessing unfulfilled potential.

\section{Conclusion: Literary Tiredness}

The three novels under discussion were the product of a time - postwar-when Britain was still recovering from a six-year, global armed conflict, was still (until 1950) subject to rationing and other austerity measures, was enduring strikes and cold winters and was feeling, in the words of a Times correspondent, 'the natural weariness of a people who have sustained great burdens for many years' ${ }^{37}$ Small wonder, then, that each of the works features instances of artistic exhaustion, instances that point to general anxiety about the future of creative endeavour. That this anxiety takes the nebulous form of a sense of malaise, rather than being fully formally realized, qualifies the three texts for the category of the literature of tiredness, a category that rises above the Baroque self-indulgence of the literature

\footnotetext{
${ }^{34}$ Anne Barnes, 'Fiction', Times [London, England] (13 October 1984), p. 17. The Times Digital Archive, accessed 9 April 2015.

${ }^{35}$ Rubin Rabinovitz, The Reaction against Experiment in the British Novel 1950-1960 (New York: Columbia University Press, 1967), p. 96.

${ }^{36}$ A. S. Byatt, Degrees of Freedom: The Early Novels of Iris Murdoch [1965] (London: Vintage, 1994), p. 141.

${ }^{37}$ A Correspondent, 'Boredom and Fatigue', Times [London, England], 18 October 1947, p. 6. The Times Digital Archive, accessed 7 April 2015.
} 
of exhaustion but does not reach the vivifying substantiality of the literature of replenishment. That instances of cultural exhaustion are presented by means of that antique literary symbol, the rose, it should be said, is not in itself indicative of fatigue. As these novels by Taylor, Eliot and Murdoch, not to mention Green's, prove, the rose, as figure, remains lushly proliferative, glowingly complex and resultantly powerful. But flowers and power are a subject for the 1960s and 1970s, and the next volume in this series. 